\title{
DESAFIOS NO ATENDIMENTO DE ENFERMAGEM A PACIENTES DO SEXO FEMININO
}

\author{
Leandro Guimarães Ribeiro ${ }^{1}$, Antonio Mateus Araujo Teixeira ${ }^{2}$ \\ ${ }^{1,2}$ Centro Universitário do Norte (UNINORTE)
}

DOI: $10.47094 /$ ICONRES.2021/16

Introdução: De acordo com Marinelli (2012), o sexo masculino apresenta maior dificuldade em trabalhar com saúde da mulher devido questões culturais intrínsecas da população e o Enfermeiro, não está excluído desse tópico, principalmente em virtude da necessidade de realização de procedimentos que envolve a intimidade da paciente. Desta forma, a timidez da paciente pode gerar constrangimento e isso dificulta a interação no atendimento. Objetivo: Relatar a experiência de um acadêmico de enfermagem em uma clínica dermatológica consultando pacientes do sexo feminino. Metodologia: Trata-se de um relato de experiência de um acadêmico de enfermagem ao participar de um estágio extracurricular em uma clínica particular em Manaus. A atividade ocorreu no período de fevereiro a junho de 2019, sendo realizada aos finais de semana, período em que existia um maior fluxo de pessoas. Os serviços eram voltados a consultas dermatológicas com público do sexo feminino e masculino. Resultados: Durante o período de atividades, percebeu-se que havia uma certa resistência por parte do público feminino. A nível de protocolo, era necessário que o paciente ficasse somente de roupa íntima, foi percebido que tal atividade gerava maior desconforto em pacientes do sexo feminino. A existência de recusa pode estar atrelada ao estigma de que o sexo masculino em algum momento pode agir desrespeitosamente, desconsiderando o lado profissional. Grande parte dessas mulheres sentiam-se assediadas somente pelo olhar do profissional. Conclusões: É comum que a mulher não se sinta confortável em uma consulta com um homem devido a realidade da sociedade. O medo, assédio, trauma dificultam a realização de um bom atendimento. É um direito da mulher não querer ser atendida por um homem, seja qual for o motivo, e é necessário que o futuro profissional saiba solucionar esses conflitos.

Palavras-chave: Constrangimento. Relações Enfermeiro-Paciente. Saúde da Mulher.

Área Temática: Atenção à saúde 